\title{
Generation and immune-characterization of single chain fragment variable (scFv) antibody recognize breast cancer cells line (MCF-7)
}

\author{
Ilham Mahgoub ${ }^{1 *}$, Ahmed K Bolad ${ }^{1}$, Mohamed Mergani ${ }^{2}$
}

From Updates on Immunotherapy of Cancer and Immunoscore Symposium, part of the Sidra Symposia Series, held in partnership with the Society for Immunotherapy of Cancer

Doha, Qatar. 22-23 January 2014

Phage display technologies were used to produce singlechain antibodies $(\mathrm{scFv})$ against breast cancer cell line (MCF-7). The mouse B cell hybridoma line C3A8 was the starting material, which generates a monoclonal antibody against breast cancer cells (MCF-7). The best candidate scFv sequences, based on (ELISA) screening data were sub-cloned into HB2151 host strain. The scFv gene was expressed in E. coli cytoplasm for further analysis. The purified $\mathrm{scFv}$ protein was characterized using western blot, flow Cytometery, indirect ELISA and immunofluorescence tests. Bioinformatics tools were used to predict heavy $(\mathrm{VH})$ and light $(\mathrm{VL})$ chains models. In the results, the protein was showed specific binding toward MCF-7 cells line when a band of $68 \mathrm{kD}$ was appeared in Western blot test. Further, scFv clearly recognized the MCF-7 antigen epitopes in immuno-fluorescence test. Additionally, 99\% of the cells numbers were bound to scFv protein as measured by flow cytometery analysis. The predicted structures of heavy and light chains were found to be acceptable and were used to predict sequential epitopes that docked against epidermal growth factor receptor on surface of MCF-7. Herein, the recombinant antibody technology is a rapid and effective approach to next generation of cancer diagnosis and immunotherapy.

\section{Authors' details}

"Microbiology and Unit of Immunology, Alneelain Medical Research Center, Faculty of Medicine, Khartoum, Sudan. ${ }^{2}$ Biotechnology Engineering, International Islamic university Malaysia (IIUM), Kuala Lampour, Malaysia.

Published: 24 February 2014

'Microbiology and Unit of Immunology, Alneelain Medical Research Center, Faculty of Medicine, Khartoum, Sudan

Full list of author information is available at the end of the article
doi:10.1186/2051-1426-2-S1-P6

Cite this article as: Mahgoub et al.: Generation and immunecharacterization of single chain fragment variable (scFv) antibody recognize breast cancer cells line (MCF-7). Journal for ImmunoTherapy of Cancer 2014 2(Suppl 1):P6.
Submit your next manuscript to BioMed Central and take full advantage of:

- Convenient online submission

- Thorough peer review

- No space constraints or color figure charges

- Immediate publication on acceptance

- Inclusion in PubMed, CAS, Scopus and Google Scholar

- Research which is freely available for redistribution
C Biomed Central

\section{Biomed Central}

